\title{
Impacts of a Parenting Newsletter on Fathers of Kindergarten Children
}

\author{
Sean E. Brotherson \\ North Dakota State University \\ Erin Kramer Holmes \\ Brigham Young University - Provo, erin_holmes@byu.edu \\ Christopher J. Bouwhuis
}

Follow this and additional works at: https://scholarsarchive.byu.edu/facpub

Part of the Other Social and Behavioral Sciences Commons

\section{Original Publication Citation}

Brotherson, S., Holmes, E. K., and *Bouwhuis, C. J. (2012). Impacts of a parenting newsletter on fathers of kindergarten children. Fathering: A Journal of Research, Theory, and Practice about Men as Fathers: Special Issue on Community Father Involvement Programs, 10(1), 31-46.

\section{BYU ScholarsArchive Citation}

Brotherson, Sean E.; Holmes, Erin Kramer; and Bouwhuis, Christopher J., "Impacts of a Parenting Newsletter on Fathers of Kindergarten Children" (2012). Faculty Publications. 4773.

https://scholarsarchive.byu.edu/facpub/4773 
See discussions, stats, and author profiles for this publication at: https://www.researchgate.net/publication/283380735

\section{Impacts of a Parenting Newsletter on Fathers of Kindergarten Children}

Article in Fathering A Journal of Theory Research and Practice about Men as Fathers · January 2012

DOI: 10.3149/tth.1001.31

CITATION

1

3 authors, including:

Sean E. Brotherson

North Dakota State University

44 PUBLICATIONS 296 CITATIONS

SEE PROFILE
READS

102

\section{Erin K. Holmes}

Brigham Young University - Provo Main Campus

61 PUBLICATIONS 745 CITATIONS

SEE PROFILE

Some of the authors of this publication are also working on these related projects:

Nurtured Heart Approach to Parenting View project

Work-family conflict View project 
*Sean E. Brotherson, Ph.D. ${ }^{1}$; *Erin Kramer Holmes, Ph.D. ${ }^{2}$; and CHRISTOPHER J. BOUWHUIS, M.S. ${ }^{3}$

\section{Impacts of a Parenting Newsletter on Fathers of Kindergarten Children}

This study is the first assessment of the perceived effectiveness of a parenting newsletter written specifically for fathers or father figures. The Father Times newsletter was distributed weekly for six weeks to all families of kindergarten children at a local school. One hundred seventy-seven fathers responded to a self-report questionnaire regarding usage of the parenting newsletter, perceptions of the newsletter as a resource, and impacts on fathers' attitudes, knowledge, behaviors, and father-child relationship quality. Two-thirds of fathers in the sample reported changing at least "somewhat" in all nine outcomes explored. Neither father age nor number of children in the home influenced fathering outcomes, but fathers with lower levels of education reported greater impacts from reading the newsletter. While the newsletter targeted fathers, $70 \%$ of mothers also read the newsletter suggesting that targeting fathers may be an effective way to continue to bring parent education to mothers. It further suggests that a fathering newsletter could be a useful tool for coparenting discussions. We conclude that directly reaching out to fathers and father figures can bridge the divide between men and parent education programs, providing an effective alternative to traditional parent education programs.

Keywords: family life education; parent education; parenting newsletters; fatherchild relationship; fathering; early childhood

While many parents need support to improve parent knowledge, increase skills, and prevent abuse (Arcus, Schvanaveldt, \& Moss, 1993; Campbell \& Palm, 2004; Martin $\&$ Weigel, 2001), education for fathers may be especially important because men's so-

\footnotetext{
${ }^{1}$ North Dakota State University.

${ }^{2}$ Brigham Young University.

${ }^{3}$ Certified Family Life Educator, Layton, Utah.

* Both authors made equal contributions to this manuscript.

Correspondence concerning this article should be sent to Sean E. Brotherson, Associate Professor, Department of Human Development and Family Science, Dept. \#7260, P.O. Box 6050, North Dakota State University, Fargo, North Dakota 58108-6050. Email: sean.brotherson@ndsu.edu.
} 
cialization to parenthood often leaves them less prepared than women for the empathy, connectedness, and responsibility good parenting requires (Brotherson, 2007; Ehrensaft, 1995). Yet parent educators regularly report that recruiting and retaining fathers is more challenging than recruiting and retaining mothers (Hawkins \& Fagan, 2001). How can parent educators reach out to fathers? We propose that a parent education newsletter targeting fathers and father figures will be an effective way to offer men the educational tools they need, and to meet men's desire for direct, individualized education (Hawkins \& Fagan, 2001; Palm, 1997).

Research on the effectiveness of newsletters has focused almost exclusively on mothers. In this article we fill this gap by exploring fathers' and father figures' usage of the Father Times newsletter, their perceptions of the newsletter as a resource, and their perceived impacts on fathers' attitudes, knowledge, behaviors, and father-child relationship quality. We further explore variations in effects by father age, father education, number of children, and perceived impact of the newsletter.

\section{INTRODUCTION}

\section{Newsletters as Effective Educational Tools for Fathers}

Newsletters target specialized populations, reduce barriers commonly associated with more formal classroom teaching, and enhance parent knowledge, confidence, and skills (Garton et al., 2003; Martin \& Weigel, 2001; Riley et al., 1991; Walker, 2005).

How might newsletters impact fathers' or father figures' parenting? Based on Bronfenbrenner's ecological theory, family life educators emphasize the interplay between individuals, families, and the larger social context (Bronfenbrenner, 1986). Ecological theory assumes that individuals develop in a multitude of systemic contexts (the microsystem, mesosystem, exosystem, and macrosystem). The two systems most relevant to the role of newsletters for fathers are the microsystem, which encompasses the relationships and interactions a father and his child have within their immediate surroundings (e.g. the interaction they have at home), and the mesosystem, which represents the connection between the father and the institutions with which he interacts (e.g., the connection between newsletters and the father, or the relationship between the kindergarten center and the father). Thus, guided by this framework, fathers should be able to enhance their skills, increase knowledge about child development, and/or be more attentive to their child's needs (e.g., interaction within the microsystem) by reading the newsletter (e.g., interaction with the mesosystem).

\section{Choosing Newsletters over Traditional Parent Education Tools for Fathers}

Traditional parent education has largely included formal parenting classes taught by a professional and offered at a specific location, but this traditional mode of parent education is becoming less feasible for many parents and educators (Duncan \& Goddard, 2005). Considering that fathers tend to be more difficult to reach, more cautious about interventions, and more private in their efforts to change (Hawkins \& Fagan, 2001), a less invasive but easy to disseminate approach, such as a newsletter sent directly to the parent's home, may be particularly appropriate for fathers. 
Parenting newsletters provide needed educational resources for parents while minimizing common obstacles such as tight budgets for families or organizations (Brotherson \& Bouwhuis, 2007; Garton et al., 2003; Malek, 2001; Riley et al., 1991), limited time, lack of transportation, availability of child care, conflicting parent work schedules, etc. (Merkowitz, Jelly, Collins, \& Arkin, 1997; Wood \& Baker, 1999). While there are still financial costs associated with newsletters, the often larger costs associated with parent education and intervention, such as speaker fees or venue fees, are no longer necessary.

How does one effectively use newsletters as a parent education tool? Martin and Weigel (2001) suggest seven key elements to making newsletters an effective parent education tool: (1) easy access; (2) easy to read; (3) a reasonable amount of information; (4) engaging style; (5) delivery to the parent's home; (6) timely or age-appropriate information about children; and (7) accurate and trustworthy information. To meet these key elements, newsletters are often distributed through reputable community centers such as a child's educational setting. Distributing newsletters through educational settings also enables educators to reach the parents of age-specific children.

Do parents read the newsletters they receive? In prior research, parents reported reading most or all of the newsletters they received, particularly if received on a monthly basis (Doescher, Pratt, Allen, \& Grobe, 1997; Garton et al., 2003). For example, parents who read "all" contents of the newsletter they received included $71 \%$ in Oregon (Doescher et al., 1997), 66\% in Wisconsin (Riley et al., 1991), and 71\% in North Dakota (Gebeke \& Klenow, 1994). More than half of the parents surveyed kept and filed the newsletters for further use (Riley et al., 1991).

Does simply reading a parent education newsletter impact parent knowledge, skills, and behaviors? Yes. Newsletters increase parent knowledge, improve confidence, and increase positive parenting behaviors (Cudaback et al., 1985; Doescher et al., 1997; Garton et al., 2003; Hughes \& Clark, 1994; Martin \& Weigel, 2001). Researchers report that newsletters provide parents with the information they crave about healthy child development (Doescher et al.; Garton et al.), and help parents gauge their child's developmental progress (Martin \& Weigel). Parenting newsletters can also boost parent self-confidence (Cudaback et al.; Hughes \& Clark; Martin \& Weigel). Mothers who read newsletters gained knowledge and received affirmation of already existing skills, which enhanced their confidence (Cudaback, et al., 1985). Over $75 \%$ of the mothers who received newsletters in one study reported that their parenting practices improved (Doescher et al.). Parents who read parenting newsletters talk to their baby more, are less angry, respond more quickly (Riley, 1991), foster more child responsibility, assist children with friendships more readily, are more respectful of their children, and manage the media environment more effectively at home (Garton et al.).

A limitation in existing research on newsletter interventions is that nearly all respondents in newsletter evaluation research have been mothers. For example, Riley et al. (1991) reported in their study that mothers made up $97 \%$ of respondents in their evaluation. Yet research suggests that the specific needs and interests of fathers need to be considered and evaluated (Hawkins \& Fagan, 2001). This study provides an op- 
portunity to address the influence of parenting newsletters as an effective parent education tool for fathers and father figures.

\section{RESEARCH QUESTIONS}

In this paper, we address the following research questions:

RQ1: To what extent will fathers/father figures read the Father Times newsletter series? Will they file the newsletter away as a future resource? Will they share it with others within the household?

RQ2: Will the newsletter impact fathers'/father figures' parenting attitudes? Parenting behaviors? Father-child relationship quality?

RQ3: How will variations in father age, education level, and perceived value of the newsletter impact its effectiveness?

\section{Methods}

\section{Procedures}

The primary researcher contacted the principal of a public kindergarten in the upper Midwest. Together the researcher and principal discussed the value of the project and made arrangements to deliver six issues of the Father Times newsletter to fathers and father figures of children in the kindergarten program. Beyond approval from the principal, all required materials were submitted and approved by the administrative officials of the local school district and approval for the study was received through the university Institutional Review Board.

Six eight-page issues of the Father Times newsletter were distributed on a weekly basis to fathers of children attending the kindergarten center. Newsletter issues covered the topics of communication, connection, play, reading, emotional intelligence, and child guidance. Each newsletter contained a story about a father and his situation ("Once Upon a Time"), research about fathers and a parenting topic (called "Fathering Facts"), child development information ("What Children Need"), suggestions for activities with fathers and children ("Time Together"), and a list of resources or books fathers and children could read together.

Following the distribution of the newsletters, each father with a child in the kindergarten program was sent a cover letter, questionnaire, and return envelope with an incentive for return of the survey (gift certificate for father and child). The questionnaire could be returned via regular mail, to the child's teacher, or at a parent involvement activity at the school. One-hundred-seventy-seven questionnaires were returned and included in the final analysis with a $42 \%$ response rate.

\section{Participants}

Participants were fathers and father figures of children attending a public kindergarten center. On average, fathers were 37 years old $(S D=6.02)$, had an average of 2.4 children $(S D=.99)$, and were primarily Caucasian $(96 \%)$, with $4 \%$ of fathers report- 
ing either African-American or Hispanic race. The majority of respondents were married (84\%), followed by separated or divorced (7\%), single and never married (4\%), living with a partner $(3 \%)$, or remarried $(2 \%)$. Half of fathers had a 4-year degree or higher $(56 \%)$, followed by "some college" (18\%), a 2-year degree (14\%), or high school/GED $(12 \%)$. The majority of participants $(89 \%)$ were the biological father of the child, but $6 \%$ were the child's stepfather, and $5 \%$ were some other type of father figure to the child.

\section{Measures}

Participants reported on key demographic variables: age, race, marital status, education level, and father type (biological, stepfather, or other).

Because we found no instruments designed specifically for evaluating newsletters targeting fathers or father figures, we adapted Riley et al.'s (1991) instrument created to evaluate the Parenting the First Year newsletter.

Usage. To assess usage of the Father Times newsletter, we included six questions on how many newsletters they received, how much of the newsletter they read, what they usually did with the newsletters, and whether anyone else read them. For example, the first question asked "How many issues of the newsletter were received?" Response options included "0," "1-3," or "4-6." The second question asked "How much of the $F a$ ther Times newsletter do you usually read?" Response options were "none of it," "skim and read 1-2 articles per issue," "most articles in most issues," or "all articles in all issues." The third question regarding newsletter usage inquired about who else read the newsletter. Answer options included "spouse or partner," "child's grandparent," "another relative or friends," “" other fathers or father figures," "co-workers," or "other." These questions are similar or identical to those asked in previous studies and allow for some means of comparison (Riley et al., 1991; Walker, 2005).

Parenting knowledge or behavior. Nine questions asked about specific aspects of parenting knowledge or behavior that may have changed "because of the Father Times newsletter." The items included "I have better understanding about my child's needs for growth and development," "I have increased knowledge of good parenting as a father," "I have a closer relationship with my child," "I am more confident in my actions as a father," "I am more actively involved with my child through play," "I have read more to or with my child," "I am more attentive to my child's needs," and "I have changed my behavior to use more positive guidance or discipline with my child." Each question used a 5-point Likert scale with responses ranging from "not at all" (1) to "somewhat" (3) to "very much" (5)

Perception of the newsletter. If fathers do not perceive the educational tool to be interesting, informative, useful in their everyday parenting, and/or worth sharing with others, the tool is unlikely to influence a father's attitudes, knowledge, or behavior. We assessed fathers' perception of the newsletter with two fixed response dichotomous questions ("I agree"//I disagree") including "For me, the Father Times newsletter was interesting to read and informative," and "For me, the Father Times newsletter was 
useful in my everyday parenting." We also asked one yes/no question, "I shared the newsletter with others."

\section{RESULTS}

The primary purpose of this study was to assess fathers' usage of the Father Times newsletter and to measure its impact on fathering knowledge, attitudes, and behavior. A secondary purpose was to better understand the ways the functional characteristics of the newsletter (e.g. perceptions of the newsletter as useful, interesting, and informative) impact its effectiveness, and to better understand the variations in effectiveness by father/father figure age, number of children, and education level.

\section{Usage of Newsletters by Fathers}

Our first research question regarded how fathers/father figures use a parenting newsletter. Forty-four percent of participants reported reading "most" or "all" articles in each issue; $46 \%$ reported "skimming and reading 1-2 articles per issue." The remaining $11 \%$ reported not reading any of the newsletters. Four primary reasons for not reading the newsletter included newsletters were sent to the child's home but were not forwarded to the father when he did not live in the child's home, the father or father figure was not home due to active military duty, lack of parental communication regarding receipt of the newsletter in the home, and lack of time (including work-related constraints).

Forty percent of the fathers/father figures in our sample kept and filed the newsletters for later use. Unfortunately the larger majority $(60 \%)$ reported that they threw the newsletters away after reading them. While fathers/father figures in this sample were not as ready to file the newsletters away as mothers have been in prior research, we did find that $73 \%$ of the men in our sample were sharing the newsletter with others within their family, with $70 \%$ reporting that their spouse or partner also read the newsletter.

\section{Perceived Newsletter Influences on Fathers' Knowledge, Attitudes, and Behavior}

A second major research question in this study concerned the perceived impacts of the Father Times newsletter on fathers' knowledge, attitudes, and behavior (see Table 1 ). The greatest impacts perceived by fathers/father figures as a result of reading the newsletter were increased knowledge of good parenting $(M=3.23, S D=.95)$, better understanding of their child's need for growth $(M=3.22, S D=.92)$, and being more attentive to their child's needs $(M=3.21, S D=1.07)$, with between $77 \%$ and $78 \%$ of fathers/father figures reporting that their knowledge, understanding, and attentiveness as a parent changed at least "somewhat" as a result of reading the newsletter. Finally, a majority of fathers $(77 \%)$ reported feeling at least "somewhat" "more confident in [their] actions related to being a father" $(M=3.17, S D=.96)$.

Regarding parenting behaviors, fathers and father figures reported being at least "somewhat" more actively involved with their children due to reading the newsletters $(M=2.98, S D=1.13)$. First, $73 \%$ of participants reported that they had at least "somewhat" "changed [their] behavior to use more positive guidance or discipline with [their] 
Table 1

Frequencies (M, SD, and Percent) for Perceived Impact of Father Times Newsletter

Variable (Impact Statement)

M SD Percent Per Response Category*

(1) (2) (3) (4) (5)

Increased knowledge of good parenting

Better understanding of child's needs for growth

More attentive to child's needs

$\begin{array}{rrrrrrr}3.23 & .95 & 3 & 17 & 32 & 30 & 7 \\ 3.22 & .92 & 1 & 18 & 37 & 24 & 8 \\ 3.21 & 1.07 & 6 & 14 & 31 & 26 & 10 \\ 3.17 & .96 & 4 & 16 & 36 & 26 & 6 \\ 3.15 & 1.10 & 6 & 17 & 31 & 22 & 11 \\ 3.04 & 1.14 & 10 & 17 & 30 & 22 & 9 \\ 3.04 & 1.15 & 10 & 19 & 24 & 29 & 7 \\ 2.98 & 1.13 & 10 & 17 & 34 & 18 & 9 \\ 2.93 & 1.06 & 8 & 22 & 33 & 17 & 7\end{array}$

More confidence in actions as a father

Change of behavior to use more positive guidance

Did some father-child activities listed

Read more with child

More active involvement with child through play

Closer relationship with child

$*(1)=$ Not at All, $(2)=$ Slightly, (3) = Somewhat, $(4)=$ Much, $(5)=$ Very Much .

child," ( $M=3.15, S D=1.10)$ with $11 \%$ reporting they changed their behavior "very much." Seventy percent reported they had at least "somewhat" "done the father-child activities listed with [their] own child" $(M=3.04, S D=1.15)$. Also, $67 \%$ reported that they at least "somewhat" "read more to or with [their] child" $(M=3.04, S D=1.14)$. Finally, 66\% percent reported that due to reading the Father Times newsletter they had at least "somewhat" developed "a closer relationship with [their] child" $(M=2.93, S D$ $=1.06$ ).

In summary, as a result of reading the newsletter, roughly two-thirds of the fathers in this sample perceived positive changes in their own behavior such as using more positive child guidance, reading more to their child, and playing or doing more activities with their child. These positive behavioral changes are likely responsible for $66 \%$ of fathers'/father figures' reporting that they at least "somewhat" developed a closer relationship with their child as a result of reading the newsletter.

\section{Impact of Perceptions of Newsletter on Newsletter Effectiveness}

We also sought to better understand how perceptions of the newsletter (e.g. worth sharing, interesting and informative, or useful in everyday life) impact its effectiveness. Three dichotomous variables indicating fathers'/father figures' responses to the newsletter include sharing it with others (yes/no), whether it was interesting to read and informative (agree/disagree), and whether it was useful in their everyday parenting (agree/disagree). A series of independent sample t-test analyses were run for each independent variable with the nine statements representing perceived impacts on father knowledge, attitudes, and behaviors. While this is a large number of t-test analyses, our rationale for proceeding with this approach rested on two criteria that we felt outweighed the disadvantages. First, since our study was an exploratory effort assessing how fathers respond to a parenting newsletter, this approach allowed us to illuminate a broad range of fathers' perceptions to our newsletter intervention. Second, it made it 
Table 2

Mean Comparisons and t-test Statistics for Father Perceptions of Newsletter as Interesting and Informative

\begin{tabular}{|c|c|c|c|c|c|c|}
\hline \multirow[t]{2}{*}{ Variable } & \multicolumn{2}{|c|}{$\begin{array}{c}\text { Fathers Agree } \\
\text { Series is Informative }\end{array}$} & \multicolumn{2}{|c|}{$\begin{array}{l}\text { Fathers Disagree } \\
\text { Series is Informative }\end{array}$} & \multirow[b]{2}{*}{$t$} & \multirow[b]{2}{*}{$d f$} \\
\hline & $M$ & $S D$ & $M$ & $S D$ & & \\
\hline $\begin{array}{l}\text { Better understanding of child's needs } \\
\text { for growth }\end{array}$ & 3.30 & .88 & 2.25 & .46 & $-3.340 * *$ & 134 \\
\hline Increased knowledge of good parenting & 3.33 & .90 & 2.00 & .53 & $-4.132 * *$ & 134 \\
\hline More confidence in actions as a father & 3.26 & .89 & 1.87 & .83 & $-4.279 * *$ & 134 \\
\hline Closer relationship with child & 3.02 & 1.02 & 1.62 & .52 & $-3.803 * *$ & 133 \\
\hline $\begin{array}{l}\text { More active involvement with child } \\
\text { through play }\end{array}$ & 3.08 & 1.08 & 1.50 & .53 & $-4.076^{* *}$ & 134 \\
\hline Did some father-child activities listed & 3.10 & 1.10 & 2.50 & 1.51 & -1.467 & 134 \\
\hline Read more with child & 3.10 & 1.14 & 2.25 & 1.04 & $-2.067^{*}$ & 134 \\
\hline More attentive to child's needs & 3.29 & 1.03 & 2.12 & .99 & $-3.107 * *$ & 133 \\
\hline $\begin{array}{l}\text { Change of behavior to use more } \\
\text { positive guidance }\end{array}$ & 3.26 & 1.06 & 1.75 & .46 & $-3.982 * *$ & 133 \\
\hline
\end{tabular}

$* p<.05 . * * p<.01$.

possible for us to examine this full range of perceptions to create future research questions and to suggest evidence-based analysis plans for future research.

Results of the t-tests indicate that fathers who agreed the newsletter series was interesting and informative were significantly more likely to report positive impacts from reading the series than fathers who disagreed with this assertion (see Table 2). For example, fathers who agreed the series was informative were more likely to report better understanding of their child's developmental needs as a result of the newsletter $(M=$ $3.30)$ than fathers who disagreed $\left(M=2.25 ; t_{(134)}=-3.340, p<.01\right)$. Fathers who found the newsletter interesting and informative also reported significantly more confidence in their fathering, increased knowledge of good parenting, a closer relationship with their child, more active involvement with their child, more reading with their child, more attentiveness to child needs, and more positive child guidance.

Further, fathers who agreed the newsletter series was useful in everyday parenting were significantly more likely to report positive impacts on knowledge, relationship, and behaviors due to reading the newsletter (see Table 3). As an example, fathers who found the series useful in their everyday parenting were significantly more likely to use positive guidance strategies with a child $(M=3.31)$ than fathers who felt the series was not useful in their daily parenting $\left(M=1.77 ; t_{(133)}=-5.297, p<.01\right)$. No significant differences were found between fathers who shared the newsletter with others and those who did not on specific outcome variables.

\section{Variations in Effectiveness by Father Age, Number of Children, and Education}

In addition, a series of one-way analyses of variance (ANOVA) were conducted to assess the influence of participants' age, number of children, and level of education on 
Table 3

Mean Comparisons and t-test Statistics for Father Perceptions of Newsletter as Useful in Everyday Parenting

\begin{tabular}{|c|c|c|c|c|c|c|}
\hline \multirow[t]{2}{*}{ Variable } & \multicolumn{2}{|c|}{$\begin{array}{l}\text { Fathers Agree } \\
\text { Series is Useful }\end{array}$} & \multicolumn{2}{|c|}{$\begin{array}{l}\text { Fathers Disagree } \\
\text { Series is Useful }\end{array}$} & \multirow[b]{2}{*}{$t$} & \multirow[b]{2}{*}{$d f$} \\
\hline & $M$ & $S D$ & $M$ & $S D$ & & \\
\hline $\begin{array}{l}\text { Better understanding of child's needs } \\
\text { for growth }\end{array}$ & 3.33 & .88 & 2.38 & .65 & $-3.732 * *$ & 134 \\
\hline Increased knowledge of good parenting & 3.38 & .86 & 2.00 & .58 & $-5.627 * *$ & 134 \\
\hline More confidence in actions as a father & 3.30 & .85 & 2.08 & 1.11 & $-4.791 * *$ & 134 \\
\hline Closer relationship with child & 3.08 & .99 & 1.62 & .51 & $-5.220 * *$ & 134 \\
\hline $\begin{array}{l}\text { More active involvement with child } \\
\text { through play }\end{array}$ & 3.14 & 1.07 & 1.62 & .65 & $-5.042 * *$ & 134 \\
\hline Did some father-child activities listed & 3.15 & 1.07 & 2.15 & 1.34 & $-3.104 * *$ & 134 \\
\hline Read more with child & 3.17 & 1.10 & 1.92 & .95 & $-3.936^{* *}$ & 134 \\
\hline More attentive to child's needs & 3.34 & 1.01 & 2.08 & .86 & $-4.353^{* *}$ & 133 \\
\hline $\begin{array}{l}\text { Change of behavior to use more } \\
\text { positive guidance }\end{array}$ & 3.31 & 1.03 & 1.77 & .60 & $-5.297 * *$ & 133 \\
\hline
\end{tabular}

$* p<.05 . * * p<.01$.

their responses to reported outcomes from reading the newsletter series. Based on the distribution of ages in this sample, the age variable was re-coded into three groups: 1 ) fathers age 33 and under, 2) fathers age 34 to 39, and 3) fathers age 40 and older. No differences were found between fathers according to age. For example, father age did not impact understanding of child development $\left(F_{(2,132)}=.371, p=.691\right)$, knowledge of good parenting $\left(F_{(2,132)}=.997, p=.372\right)$, reading more with a child $\left(F_{(2,132)}=\right.$ $.608, p=.546)$, or offering positive child guidance $\left(F_{(2,132)}=.160, p=.852\right)$, or any other measured outcomes.

Based on the distribution of number of children in this sample, we created a new variable consisting of three levels in the analysis ( 1 child, 2 children, and 3 children or more). Results revealed no statistically significant differences between groups on any of the outcomes. For example, the number of children did not impact understanding of child development $\left(F_{(2,134)}=1.595, p=.207\right)$, reading more with a child $\left(F_{(2,134)}\right.$ $=.319, p=.727)$, a closer relationship with his child $\left(F_{(2,134)}=.294, p=.746\right)$, increased confidence $\left(F_{(2,134)}=.953, p=.388\right)$, or any other outcomes measured.

Finally, analyses of variance were conducted to examine whether fathers of differing education levels would respond differently to perceived impacts of the newsletter on their knowledge, attitudes, or behaviors with children (see Table 4). The participant's education level was re-coded into three levels that included: (1) some high school to high school/GED; (2) some college to 2-year degree; and (3) 4-year college degree or higher. Results of one-way ANOVAs indicated statistically significant differences between fathers of varying education levels on six of nine newsletter response variables, with two other dependent variables bordering on statistical significance. Specifically, in response to reading the newsletter series, fathers at the lowest education level (some high school/GED) were significantly more likely to report greater confidence in their 
Table 4

Group Comparisons by Education Level on Responses to Newsletter Impact (ANOVA)

\begin{tabular}{|c|c|c|c|c|}
\hline & $\begin{array}{c}\text { Some High } \\
\text { School or GED } \\
\text { (a) }\end{array}$ & $\begin{array}{c}\text { Some College or } \\
\text { 2-Yr. Degree } \\
\text { (b) }\end{array}$ & $\begin{array}{c}\text { 4-Yr. College } \\
\text { Degree or Higher } \\
\text { (c) }\end{array}$ & $F$ \\
\hline & $M \quad(S D)$ & $M \quad(S D)$ & $M \quad(S D)$ & \\
\hline Better understanding of child's needs & $3.63(1.01)$ & $3.27(.83)$ & $3.10(.92)$ & 2.67 \\
\hline Increased knowledge of good parenting & $3.63(.68)^{\mathrm{c}}$ & $3.40(.96)$ & $3.04(.96)$ & $4.02 *$ \\
\hline More confidence in actions as a father & $3.79(.54)^{\mathrm{b}, \mathrm{c}}$ & $3.20(.84)$ & $2.99(1.05)$ & $5.63 * *$ \\
\hline Closer relationship with child & $3.74(.93)^{\mathrm{c}}$ & $2.91(.99)$ & $2.72(1.06)$ & $7.46^{* *}$ \\
\hline More active involvement through play & $3.68(.89)^{\mathrm{c}}$ & $3.02(1.14)$ & $2.75(1.12)$ & $5.51 * *$ \\
\hline Did some father-child activities listed & $3.21(1.08)$ & $2.78(1.06)$ & $3.15(1.19)$ & 1.76 \\
\hline Read more with child & $3.58(.84)$ & $3.04(1.09)$ & $2.89(1.24)$ & 2.74 \\
\hline More attentive to child's needs & $3.79(.79)^{\mathrm{c}}$ & $3.16(1.00)$ & $3.10(1.16)$ & $3.27 *$ \\
\hline Change of behavior to be more positive & $3.79(.71)^{\mathrm{c}}$ & $3.23(.96)$ & $2.93(1.21)$ & $4.94 * *$ \\
\hline
\end{tabular}

Notes. $* p<.05$. ** $p<.01$. Alphabetic superscripts in the first data column indicate differences between group mean scores that are statistically significant at the $p<.05$ level.

actions as a father $(M=3.79, S D=.54)$ than fathers at each of the higher education levels (some college/2-yr. degree, $M=3.20, S D=.84$, and 4-yr. degree or higher, $M=$ $\left.2.99, S D=1.05, F_{(2,133)}=5.63, p<.05\right)$. Fathers at the lowest education level were also significantly more likely to indicate greater effects than the other two groups due to reading the newsletter on increased knowledge of good parenting, having a closer relationship with their child, being more actively involved through play, being more attentive to child needs, and changing behavior to use more positive guidance with children.

\section{DiscuSsion}

While some assessments of parenting newsletters exist, no prior research exists on newsletters targeting fathers/father figures, thus our article is among the first assessments of a parenting newsletter written specifically for fathers or father figures. In this discussion, we highlight fathers' usage of the newsletters and perceived impacts on father knowledge, attitudes, and behaviors. We also highlight variations in fathers' perceptions of the newsletter.

\section{Fathers' Usage of the Newsletter}

Similar to the findings of Doescher et al. (1997) and Garton et al. (2003), most participants in this study (about 90 percent) read the Father Times newsletter they received. About half read all or most of the newsletter. Thus, fathers seem just as likely to read newsletters as mothers when the newsletter specifically targets them. Spouses of respondents are also likely to read the newsletter. This indicates that the newsletter could be a tool for mothers even when the newsletter targets fathers, and could be a useful tool for coparenting discussions within couples. 
Unfortunately, unlike other studies who reported that up to $60 \%$ of respondents filed the newsletters for further use (Riley et al., 1991), only $40 \%$ of fathers in our sample saved them for future use. Longitudinal explorations of knowledge retention related to the newsletter could help us see what the long-term impact of the newsletters is when fathers do not save the information for future use.

It is important to note that not all fathers received the newsletters sent to them. Because newsletters were sent to the homes of all kindergartners, not all newsletters were received by fathers who were non-resident (e.g. child primarily lived with mother, or father was away on active military duty). This highlights the continued need to find better ways to reach out to fathers in non-traditional family circumstances.

\section{Perceived Newsletter Influences on Fathers' Attitudes and Behaviors}

Most fathers in this study felt that reading the Father Times newsletter increased their knowledge of parenting and child development, amplified their confidence, enhanced father-child closeness, and improved their positive parenting behaviors. Two-thirds to three-quarters of the participants read more with their child, played more with their child, used more positive discipline, and tried the father-child activities suggested in the newsletter. Such results are consistent with prior research on the effectiveness of parenting newsletters for mothers (e.g., Cudaback et al., 1985, Doescher et al., 1997; Garton et al., 2003; Hughes \& Clark, 1994; Riley et al., 1991; Walker, 2005) confirming that fathers respond well to newsletters.

Fathers' assessment of the newsletter's informativeness and usefulness in parenting both significantly contributed to how fathers/father figures responded to the newsletter in their parenting knowledge and efforts. Those men who found it interesting to read and informative were much more likely to report increased knowledge about a child's needs and good parenting, greater confidence as a father, a closer relationship with their child, and increased efforts to be more involved through play or to use more positive guidance.

Similarly, fathers who found it useful in everyday parenting were more likely to say they gained knowledge from reading the newsletter, increased their confidence, and became more engaged with their child through play, reading, or other activities.

Prior research indicated that parents often find newsletters to be useful (Martin \& Weigel, 2001; Riley et al., 1991; Walker, 2005), and that characteristics such as appeal, usefulness, and trustworthiness help facilitate positive educational impact (Doherty, 1995; Martin \& Weigel, 2001). This project extended such findings by showing that the degree to which an individual finds a newsletter's content to be informative or useful influences their likelihood of reporting positive effects due to reading the newsletter.

Age of the parent, number of children (e.g."first-time" versus experienced parents), and education level have all been cited as possible correlates of parental responses to a newsletter intervention (Bogenschneider \& Stone, 1997; Riley et al., 1991). Neither a father's age nor the number of children in his home was significantly related to perceived impact of the newsletter on father's knowledge or behavior. This finding contrasts with previous research that suggests that age of the parent (younger versus older parents) and first-time parent status are likely to influence parent response to the newsletter (Bogenschneider \& Stone; Riley et al.). For fathers, perhaps, these factors 
may be less consequential in how they respond to a newsletter resource, though the inclusion of a larger population of fathers at a younger age or fathers close to the time of a first child's birth rather than at kindergarten age may alter such findings.

Consistent with prior research, fathers with lower levels of education reported greater impacts from reading the newsletter (Bogenschneider \& Stone, 1997; Riley et al., 1991). It may be that individuals with less exposure to formal education perceive a greater need for information on parenting from formal sources, are more willing to read and apply information from such a source, or place greater trust in information received from formal sources on parenting. Also, individuals with a higher level of education may begin their parent education at a fairly high threshold, while individuals with less education may have less certainty and therefore begin at a more modest level with higher "growth potential." It is also important to note, however, that the majority of participants at different age or education levels found the newsletter resource to be beneficial, thus fulfilling the aim of the newsletter intervention to encourage positive parental knowledge and behaviors among a variety of fathers and father figures.

\section{Implications for Practice}

To our knowledge this is the only study that evaluates the effects of a parenting newsletter designed specifically for fathers. Targeting fathers of young children appears to be an effective mechanism for bridging the divide between men and parent education programs (Fagan \& Palm, 2004; Palm, 1997). The majority of the fathers and father figures we targeted read the newsletter and found it instructive, informative, and useful. We believe that directly reaching out to fathers can provide an effective alternative to traditional parent education programs.

Additionally, this newsletter provides a perceived benefit to fathers across the fathering spectrum regardless of their age or the number of children they have. Less educated fathers (i.e. those with less than or the equivalent of a high school degree) reported greater impacts on their knowledge of parenting, confidence as fathers, and efforts to read more or be more actively involved with their children through reading the newsletter. Thus, fathering newsletters have great potential to help less educated fathers improve their parenting confidence and parenting skills. Further research will be needed to discern if there are additional demographic or socioeconomic variables that may influence fathers' response to this resource, however our results suggest the newsletter should be of interest to those who wish to broadly influence fathers of young children in settings such as preschool, child care, Head Start, or kindergarten.

The newsletter resource for fathers and father figures of young children may also fit into the educational or service mission of a variety of organizations and settings. In this study, it was adopted for usage and distribution in a community kindergarten setting and delivered over a fairly short time period ( 6 weeks). Since the newsletter resource contains multiple issues and is available in both English and Spanish, it has been utilized in elementary schools, home visitation programs, Head Start programs, and other settings to facilitate outreach to fathers of young children. Such organizations can adapt the resource to their own needs and fit it within the framework of their own mission, using it to reach fathers or even to provide training for staff members. In addition, the resource could be used as a supplement in parent education courses or other settings to existing interventions, rather than serving as a stand-alone resource only. 
This study also highlights that a parenting newsletter may overcome some already existing barriers in parent education, particularly with fathers. While most newsletter studies have examined what are called "age-paced" parenting newsletters synchronized to a child's specific age, this newsletter adapted the approach to use an age-linked (ages 0 to 6 ) and gender-focused appeal to fathers and father figures. A significant number of fathers mentioned that they appreciated the focus of educational material specifically to them as fathers.

While the material was addressed to fathers, it was evident that many mothers also read the material and appreciated it (70\% reported that their spouse/partner also read the newsletter). This finding suggests that such a resource can stimulate discussion of parenting or child needs within the broader context of a father's immediate social network, which research has shown is a valuable component of such educational endeavors (Walker, 2005).

Additional barriers that newsletters may overcome include the cost of educational programs and time constraints, as well as possible preferences for privacy and caution among men regarding their parenting efforts (Hawkins \& Fagan, 2001). This study documents the potential success of newsletters in bypassing such barriers and helping to facilitate positive parenting responses by fathers with their young children.

\section{Study Limitations and Future Research}

Conclusions drawn from this study are limited by a few important conditions. First, these self-reported data may not accurately reflect actual behavior. Second, those parents who were more inclined to read the newsletter or respond positively to it may also be more likely to respond to the study survey. Since this study was an initial effort with fathers specifically and it was desirable to compare findings to previous studies, usage of a self-report survey process was helpful, however, future efforts may find value in extending this research by using reports of other observers (spouse, teacher, etc.), behavioral observations, or other measurable indicators of knowledge or behavior change. In addition, a randomized experimental design could minimize selection biases.

Another limitation of this study is that it does not explore long-term effects as a result of reading the newsletter. Many of the newsletter effects, as reported by participants, may not endure for long periods of time. Further, no control group existed in the study design and therefore it is not possible to determine if other factors also influenced participants' reports. Future research efforts in this area will benefit from the usage of treatment-control group experimental designs that offset the limitations of single-group studies and also through assessing participants in a longitudinal manner.

A limitation to this overall study was the homogeneous nature of the sample and the small sample size of participants in categories that might allow for further analysis of differences, such as father type (stepfather, etc.), employment status, race, and other such characteristics. Future efforts would benefit significantly from a sample with greater diversity in such characteristics.

Prior research indicates that the optimal time span for delivering each newsletter issue is between two weeks and one month. The newsletter for this study was released over the short time span of six weeks, one issue being released to parents each week. This may not have been sufficient time for many of the participants to finish reading the 
newsletter and do the activities they desired with their child(ren). This was also a pilot study for this newsletter, meaning that only six of the nine newsletter issues were distributed to parents and, as stated, the time span for distribution was shorter than recommended. Results may differ somewhat in future studies if all issues of the newsletter are distributed over a longer time period.

Though the response rate for this study was approximately 42 percent, it was quite comparable to response rates reported in prior newsletter research (Bogenschneider \& Stone, 1997; Riley et al., 1991; Walker \& Riley, 2001). There were some minor challenges in the distribution of the newsletter and collection of the questionnaires. A number of fathers and father figures who reported that they did not receive the newsletter made the comment that they would have read it had they received it. While a return envelope was provided with the questionnaire, these envelopes were not addressed and stamped for return. A few questionnaires were returned by mail, suggesting that more may have been received if the envelopes were stamped. A return address was included on the questionnaire. Most questionnaires were returned via the child's teacher or at a father involvement activity. A higher return rate would have yielded better overall data.

This study has answered some questions and also sets the stage for future research opportunities. Future research involving fathers who may not have custody of their children should consider the issue of family status and make efforts to reach the non-custodial parent for their feedback as well. Future research should continue to be conducted that assesses the content and effectiveness of parenting newsletters, particularly for fathers and father figures. A possible approach in future research would be to not only assess the usefulness of these newsletters from fathers' perspectives, but also to assess the effectiveness of the newsletters from mothers' perspectives. Such research would provide further insight as to the newsletter's impact on parenting and how men and women share or perceive the same information. For example, it may be of interest to learn whether reports from fathers and mothers agree and to what extent they do so. Gaining the insight of mothers regarding newsletters for fathers and father figures may also enable some degree of assessment of potential barriers that might exist between separated or divorced parents that limit dissemination of parent education to fathers through newsletters.

Parenting newsletter research thus far has examined newsletters specifically and separately with mothers, and only minimally with fathers. In future efforts, newsletters could be combined to include sections that specifically address both fathers and mothers. Such parenting newsletters may influence mothers, mother figures, fathers, and father figures to increase recognition, respect, and support for the importance of both roles in the growth and development of children, as well as the interactions between parents and with others (Walker \& Riley, 2001).

\section{ConClusion}

In conclusion, the Father Times parenting newsletter for fathers and father figures of young children has significant potential as an effective parenting resource. Our results suggest that fathers not only read the newsletter regularly, but also perceive benefits of the newsletter on parenting knowledge, attitudes, and behaviors. Results further suggest that less educated fathers (e.g. those with a high school education only) find the 
newsletter particularly beneficial, and the ease with which parent educators and other community organizations can disseminate newsletters make them an easy, cost-effective way to serve fathers in a variety of settings (e.g. preschool, Head Start, kindergarten, as a supplement to already existing courses, etc.).

\section{REFERENCES}

Arcus, M.E., Schvaneveldt, J.D., \& Moss, J.J. (Eds.). (1993). Handbook of family life education: The practice of family life education (Vol. 2). Newbury Park, CA: Sage Publications.

Bogenschneider, K., \& Stone, M. (1997). Delivering parent education to low and high-risk parents of adolescents via age-paced newsletters. Family Relations, 46, 123-134.

Bronfenbrenner, U. (1986). Ecology of the family as a context for human development. Developmental Psychology, 22, 723-742.

Brotherson, S.E. (2007). Supporting fathers through educational programs: Promising strategies and positive successes. In S.E. Brotherson \& J.M. White (Eds.), Why fathers count: The importance of fathers and their involvement with children (pp. 395-406). Harriman, TN: Men's Studies Press.

Brotherson, S.E., \& Bouwhuis, C.J. (2007). Reaching fathers in parent education: Perceptions of newsletter value among fathers and father figures. Journal of Extension, 45(3) [On-line]. Available from http://www.joe.org/joe/2007june/a3p.shtml.

Campbell, D., \& Palm, G.F. (2004). Group parent education: Promoting parent learning and support. Thousand Oaks, CA: Sage Publications.

Cudaback, D., Darden, C., Nelson, P., O’Brien, S., Pinsky, D., \& Wiggins, E. (1985). Becoming successful parents: Can age paced newsletters help? Family Relations, 34, 271-275.

Doescher, S., Pratt, C., Allen, T., \& Grobe, D. (1997). Parenting the first year newsletter evaluation: Final report. Corvallis, OR: Oregon State University Extension Service. [on-line] Available from http://osu.orst.edu/Dept/ehe/development_pt.htm.

Doherty, W.J. (1995). Boundaries between parent and family education and family therapy: The levels of family involvement model. Family Relations, 44(4), 353-358.

Duncan, S.F., \& Goddard, H.W. (2005). Family life education: Principles and practices for effective outreach. Thousand Oaks, CA: Sage Publications.

Ehrensaft, D. (1995). Bringing in father: The reconstruction of mothering. In J.L. Shapiro, M.J. Diamond, \& M. Greenberg (Eds.), Becoming a father (pp. 155-165). New York: Springer Publishing.

Fagan, J., \& Palm, G. (2004). Fathers and early childhood programs. Clifton Park, NY: Delmar Learning.

Garton, M., Hicks, K., Leatherman, M., Miltenberger, M., Mulkeen, P., Nelson-Mitchell, L., \& Winland, C. (2003). Newsletters: treasures or trash? Parenting newsletter series results in positive behavior changes. Journal of Extension [On-line], 41(1). Available at: http://www.joe.org/ joe/2003february/rb5.shtml.

Gebeke, D., \& Klenow, D.J. (1994). Parenting the first year: A summary of effectiveness evaluations of a parenting newsletter. Fargo, ND: North Dakota State University Extension Service.

Hawkins, A.J., \& Fagan, J. (2001). Clinical and educational interventions with fathers: A synthesis. In J. Fagan \& A.J. Hawkins (Eds.), Clinical and educational interventions with fathers (pp. 285-293). New York: The Haworth Press, Inc.

Hughes, R., \& Clark, C.D. (1994). An evaluation of a newsletter intervention for divorced mothers. Family Relations, 23(3), 298-309. 
Malek, F. (2001). Parenting the second and third year newsletter evaluation report. Manitowoc County, WI: University of Wisconsin Cooperative Extension.

Martin, S.S., \& Weigel, D.J. (2001). Age-paced parenting materials and child maltreatment: Can newsletters make a difference? Paper presented at the National Council on Family Relations, November 2001, Rochester, New York.

Merkowitz, R.F., Jelly, K., Collins, E., \& Arkin, C.F. (1997). Backpack buddies: A newsletter series for parents. [14 paragraphs]. Journal of Extension, 35(5). Available from http://www.joe. org/joe/1997october/iw3.html.

Palm, G.F. (1997). Promoting generative fathering through parent and family education. In A.J. Hawkins \& D.C. Dollahite (Eds.), Generative fathering: Beyond deficit perspectives (pp. 167182). Thousand Oaks, CA: Sage Publications.

Riley, D., Meinhardt, G., Nelson, C., Salisbury, M.J., \& Winnett, T. (1991). How effective are age-paced newsletters for new parents? A replication and extension of earlier studies. Family Relations, 40(3), 247-253.

Walker, S.K. (2005). Use of a parenting newsletter series and other child-rearing information sources by mothers of infants. Family and Consumer Sciences Research Journal, 34(2), 153172.

Walker, S.K., \& Riley, D. (2001). Involvement of the personal social network as a factor in parent education effectiveness. Family Relations, 50, 186-193.

Wood, W.D., \& Baker, J.A. (1999). Preferences for parent education programs among low socioeconomic status, culturally diverse parents. Psychology in the Schools, 36(3), 239-247. 
Copyright of Fathering: A Journal of Theory, Research, \& Practice about Men as Fathers is the property of Men's Studies Press and its content may not be copied or emailed to multiple sites or posted to a listserv without the copyright holder's express written permission. However, users may print, download, or email articles for individual use. 